\title{
Ecologically safe regulation of quantity of arthropods of phytophags of plants of genus Sambucus $L$.
}

\author{
O. Sylchuk, \\ M. Lisovyi, \\ Doctor of Agricultural Sciences \\ S. Vyhera, \\ Candidate of Agricultural Sciences \\ O. Taran, \\ Candidate of Biological Sciences \\ Natsionalnyy University of Life and Environmental Sciences of Ukraine \\ P. Chumak, \\ Candidate of Biological Sciences \\ V. Kovalchuk, \\ Botanichnyy Garden of Acad. OV Fomina Street. Simon Petliura
}

The purpose. To investigate mechanisms of regulation of quantity of hazardous organisms on different kinds of elder in conditions of human settlements of Ukraine. Methods. Conventional methods of faunistic research in entomology, population ecology, protection of plants. Results. The natural flora of Ukraine includes 3 kinds of plants of genus Sambucus L.: black elder, red elder, herbaceous elder. In botanic gardens of Kiev they cultivate nearly 20 forms and varieties of mainly black and red elder. It is determined that there are 9 kinds of arthropods of phytophags from 2 classes, 6 divisions and 8 families which parasitize on them. The most numerous and nocuous of them are: white American butterfly, elder aphid, and web-mite. Conclusions. For protection of plants of an elder from harmful phytophags in conditions of botanic gardens and human settlements it is recommended to use vegetable specimens Phytochelate-1 and Complexon-2p (rape-seed oil with emulsifier and garlic extract with density of $1 \%$ (100 g/10 I of water).

Key words: elder, phytochelate, elder aphid, American white butterfly, phytotoxicity.

We know that in recent years, particular attention is paid to the peculiarities of formation and functioning urbofitotsenoziv.

Research shows that creating fitodyzaynovyh compositions in terms of human use areas, the scientific rationale in different zones, as introduced and native species of trees and shrubs.

One example of effective management of plant communities include botanical gardens with exotic [8, 9] ethnic and plants of national and local importance in educational institutions; urbanolandshaftni parks in cities, towns and villages, including as with ethnic tint; floristic recreation areas, including the area around the house; urbanolandshaftni fitosmuhy various purposes, etc.

Recently, the plant genus Sambucus L. (Elder, Russ.) Looking to acquire the status of planting and use in confectionery and pharmaceutical industries. Elderberry (Sambucus nigra L.) and Canadian elderberry (Sambucus canadensis L.) can be grown on land unsuitable for fruit and berry gardens [8].

Introduction to new and innovative culture of fruit plant requires study circle pests trophic associated with these plants.

The aim of study was to investigate the composition of species of pests that damage the plant genus Sambucus L. in conditions and forest steppe zones of Ukraine.

Research Methodology. Research conducted in the Botanical Garden of them. OV Fomin Kiev University. Shevchenko (from 1986) and forest edges Lyubomlsky Volyn region (2014-2016.). Detection 
and determination of arthropod-herbivores were carried out $[2,3,4,5,6,10,12,13,16,17]$. Research, monitoring and identification of pathogens caused by fungi was carried out according to recommendations $[1,7,11,18]$.

Research Methodology. Research conducted in the Botanical Garden of them. OV Fomin Kiev University. Shevchenko (from 1986) and forest edges Lyubomlsky Volyn region (2014-2016.). Detection and determination of arthropod-herbivores were carried out $[2,3,4,5,6,10,12,13,16,17]$. Research, monitoring and identification of pathogens caused by fungi was carried out according to recommendations $[1,7,11,18]$.

Research Methodology. Research conducted in the Botanical Garden of them. OV Fomin Kiev University. Shevchenko (from 1986) and forest edges Lyubomlsky Volyn region (2014-2016.). Detection and determination of arthropod-herbivores were carried out $[2,3,4,5,6,10,12,13,16,17]$. Research, monitoring and identification of pathogens caused by fungi was carried out according to recommendations $[1,7,11,18]$.

With regular annual (from 1986) surveys of plants of Sambucus L. to identify the arthropod herbivores, we noticed that they found 9 species belonging to 2 classes, 6 rows and 8 families (Table. 1).

Table 1. The species composition of arthropods, herbivores detected on plants in the genus Sambucus L. steppes of Ukraine (Botanical Garden to them. Fomin (2012-2016).

\begin{tabular}{|c|c|c|}
\hline Class, type & Some, family & The detection rate \\
\hline \multicolumn{3}{|l|}{ Insects (Insecta) } \\
\hline $\begin{array}{l}\text { thrips buzynovyy } \\
\text { (Thrips sambuci Heeger) }\end{array}$ & Thysanoptera, Thripidae & ++ \\
\hline $\begin{array}{l}\text { aphids buzynova } \\
\text { (Aphis sambuci L.) }\end{array}$ & Homoptera, Aphididae & +++ \\
\hline $\begin{array}{l}\text { unpaired bark beetle } \\
\text { (Xyleborus dispar F.) }\end{array}$ & Coleoptera, Scolytidae & + \\
\hline $\begin{array}{l}\text { golden flower chafer } \\
\text { (Cetonia aurata L.) }\end{array}$ & Coleoptera, Scarabaeidae & $(+)$ \\
\hline $\begin{array}{l}\text { Helen hairy } \\
\text { (Epicometis hirta Poda) }\end{array}$ & Coleoptera, Scarabaeidae & ++ \\
\hline $\begin{array}{l}\text { American white butterfly } \\
\text { (Hyphantria cunea Drury) }\end{array}$ & Lepidoptera, Arctiidae & ++ \\
\hline $\begin{array}{l}\text { Fly-v buzynovyy } \\
\text { (Liriomyza amoena M.G.) }\end{array}$ & Diptera, Agromyzidae & + \\
\hline \multicolumn{3}{|l|}{$\begin{array}{l}\text { Arachnids } \\
\text { (Arachnoidae) }\end{array}$} \\
\hline $\begin{array}{l}\text { tick buzynovyy } \\
\text { (Epitrimerus trilobus Nal.) }\end{array}$ & Acariformes, Eriophyidae & ++ \\
\hline $\begin{array}{l}\text { Ordinary spider mite } \\
\text { (Tetranychus telarius L.) }\end{array}$ & $\begin{array}{ll}\text { Acariformes, } & \text { Tetranychidae }\end{array}$ & +++ \\
\hline
\end{tabular}

Note. +++ - often happens in large numbers, ++ - occurs in normal quantities + - rare, $(+)$ - happens very rarely.

We first discovered in the area of the botanical garden to them. OV Fomin on elderberry American white butterfly (Hyphantria cunea Drury) who is the object of Plant Quarantine of Ukraine and Europe.

In the towns of Volyn region Lyuboml district American white butterfly is not found in elderberry, as well as other woody plants.

In the towns of Volyn region Lyuboml district American white butterfly is not found in elderberry, as well as other woody plants. 
The most common terms in the botanical garden to them. OV Fomin on elder also has such phytophagous insects with piercing-sucking mouthparts as buzynova aphids, thrips buzynovyy, spider mites usual.

In the area of elder survey of plantations. Liuboml a large number of marked only buzynova aphids and spider mites normal

Due to damage elderberry leaves insect phytophages with piercing-sucking mouthparts causes the leaves that curl and change color.

Significant damage listed above elderberry dominant insect phytophages indicates the need to study the characteristics of their biology, ecology and nature trofolohiyi hazard with further development on this basis of environmental protection of plants against insect herbivores.

We found that white American butterfly winters in adult stage. The most severely damages the elder and white mulberry (Morus alba L.) during fruit formation and their maturation (Fig. 1.2).

Buzynova aphids overwinter in the egg stage. The largest number of herbivores observed on the plants during their kvituvannya. Since mid-September and a decrease in temperature to $0^{\circ} \mathrm{S}$ formed on leaves isolated colonies (8-30 copies.) Of larvae and winged animals (Fig. 3), which lay their eggs on plants elder.

Ordinary spider mite most severely harming the plants that grow in the sun. During hot summers and low humidity mass reproduction of mites causes decrease decorative plants.

High health requirements for the use of synthetic chemicals in terms of botanical gardens and green spaces encourage settlements in search of environmentally friendly crop protection plant collections of arthropod herbivores.

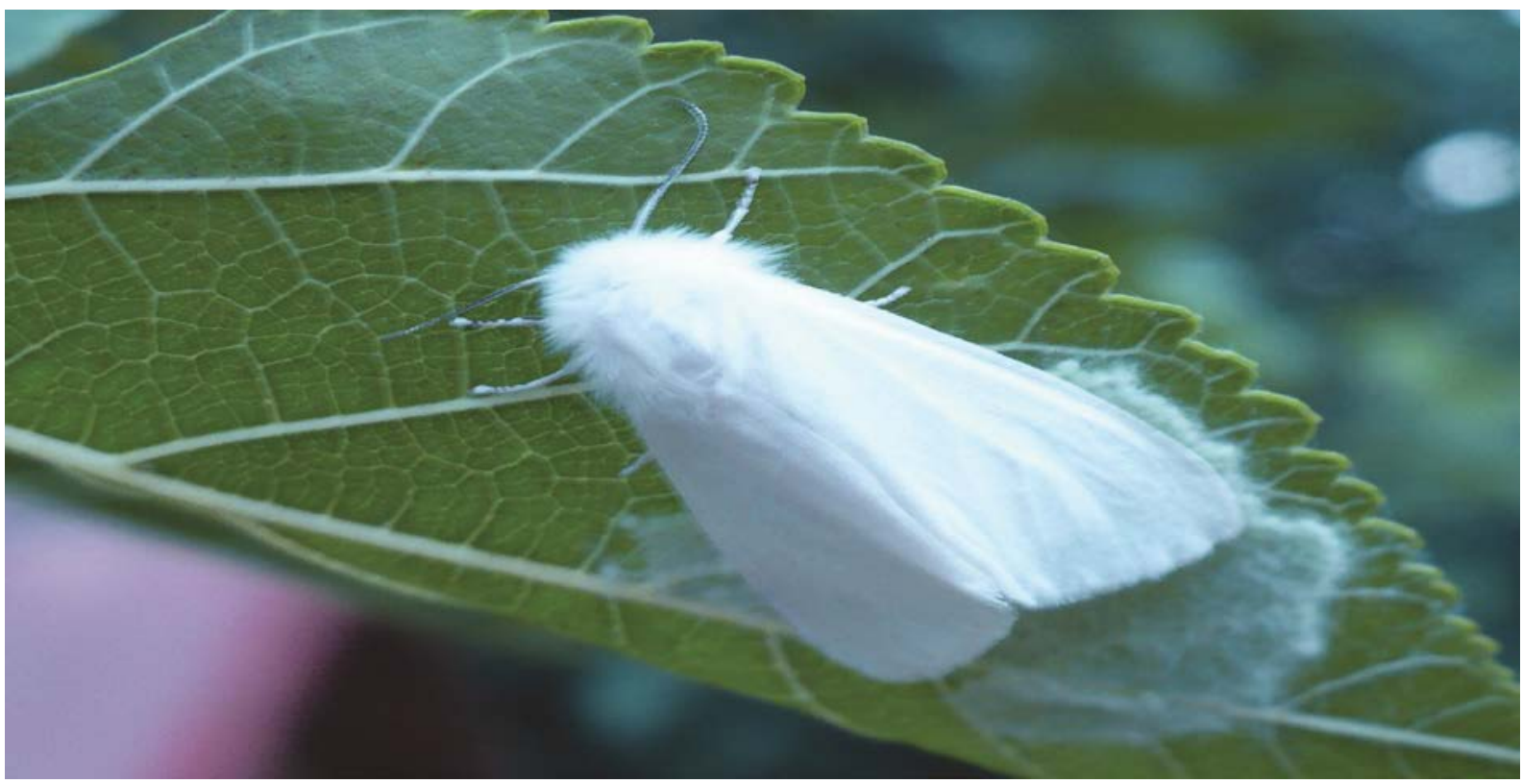

Fig. 1. The American white moth (Hyphantria cunea Drury Hyphantria cunea Drury). The female lays eggs (orig. Photo). Botanical Garden to them. OV Fomin Kiev University. Shevchenko (2015). 


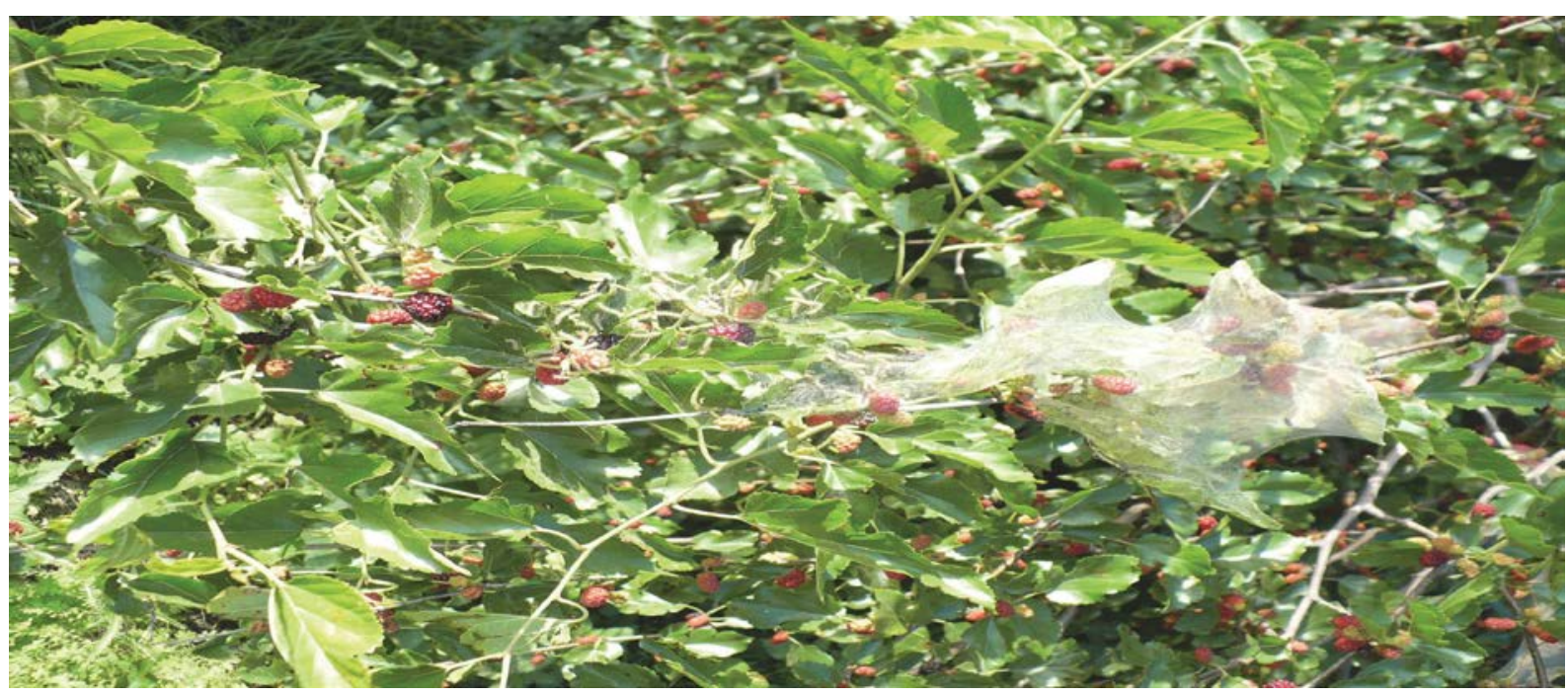

Fig. 2. Damage to Mulberry American white butterfly (Hyphantria cunea Drury) during fruit formation (orig. Photo). (Botanical Garden to them. Fomin Kiev University. Shevchenko (2015).

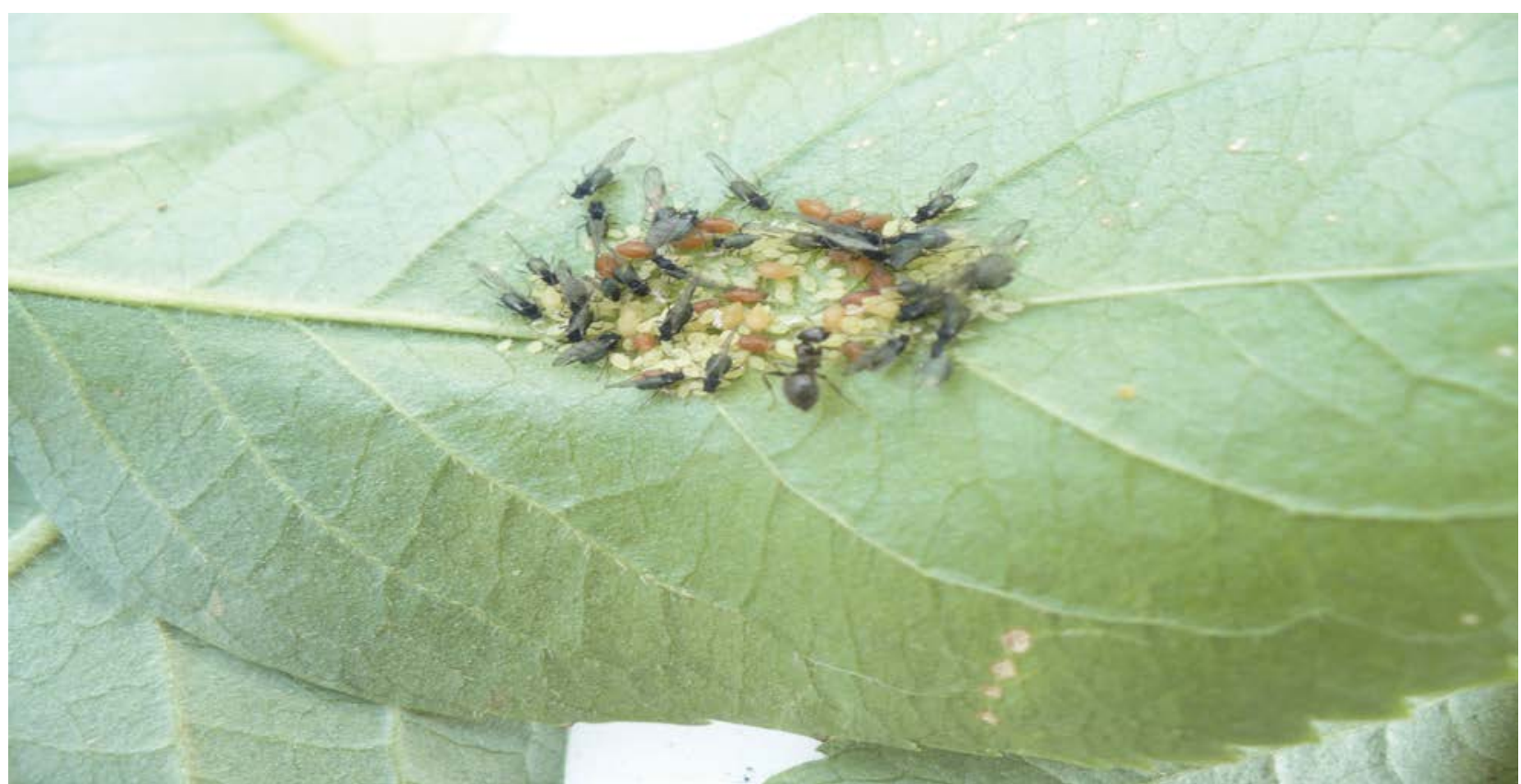

Fig. 3 Colonia buzynovoyi aphid (Aphis sambuci L.) on a piece of elderberry (orig. Photo). Uzlissya Lyubomlsky Forestry Volyn region (2016).

We have developed new drugs based on rapeseed oil, emulsifiers and certain insecticidal plants. Preparations Fitokomplekson-1 [14] and complexone-2P [15], which received patents for utility models include the following components.

Fitokomplekson 1 includes rapeseed oil, emulsifier, and tobacco dust collected in the phase kvituvannya celandine. The drug is produced by water extracts of plant material with added emulsifier. Technology of the working fluid fitokompleksonu-1 includes the following:

- $0.4 \mathrm{~kg}$ of dried and minced raw celandine Pour 4 liters of warm water and insist 5:00 filtered solution;

- $0.4 \mathrm{~kg}$ of tobacco dust pour 4 liters of warm water and insist 5:00 filtered solution;

- $0,05 \mathrm{~kg}$ of rapeseed oil and $0.05 \mathrm{~kg}$ emulsifier are mixed, the resulting mixture is poured 2 liters of warm water and stir again carefully.

For spraying plants from pests all resulting solution was poured into each dishes, stir thoroughly and immediately used. 
Complexone-2P contains rapeseed oil, emulsifier, tobacco dust and bitter as peppers wt.\%: Water extract of tobacco -4.0 , bitter pepper -5.0 , rapeseed oil with emulsifier -1.0 . The drug is produced by water extracts of plant material. The preparation technology includes the following:

- dry plant material crushed, taking $0.4 \mathrm{~kg}$ (tobacco) and $0.5 \mathrm{~kg}$ (bitter pepper) and infused in 6 liters of water for 5 hours, the solution was filtered;

- separately mixed with rapeseed oil emulsifier for the ratio of $1: 1$;

- spraying plants from pests in 4 liters of water was dissolved $0.1 \mathrm{~kg}$ of the mixture of oil and emulsifier pour 6 liters of plant material infused with tobacco and pepper and mix thoroughly with subsequent use.

Aktofit drug, used $0.2 \% \quad 0.8 \%$ and preparations Fitokomplekson-1 and 2n-complexone - a $1.0 \%$ concentration of the working fluid.

Study of toxic effects of drugs Fitokomplekson-1 and 2n-complexone buzynoviy on aphids, white American butterfly and spider mites usual showed that compared with biological agents Aktofit $0.2 \%$ (standard) was the most effective drug Fitokomplekson-1 (tab. 2). Phytotoxic action of drugs on these concentrations are not observed.

Most effective against American white butterfly was drug Fitokomplekson-1 technical efficiency which the 5 th day was $-91.7 \%$, higher biological Aktofit $0.2 \%$ (standard) is $14.7 \%$.

The most effective against aphids buzynovoyi also a drug Fitokomplekson-1 technical efficiency which the 5 th day was $-89.3 \%$, higher biological Aktofit $0.2 \%$ (reference) to $4.1 \%$.

Against spider mite usual technical efficacy Aktofit $0.2 \%$ (standard) and Fitokomplekson 1 on the 5th day was at and was - $84 \%$, and the drug-complexone $2 n$ - even below the standard of $3.0 \%$ (81\%) (see. Table. 2). This may depend on physiological characteristics mites or other insect should select plants and drugs that are more effective protection of green spaces in towns of ticks.

Table 2. The effectiveness of the protection of elderberry arthropod-herbivores (Botanical Garden to them. Fomin (2012-2016).

\begin{tabular}{|l|l|l|l|}
\hline \multirow{2}{*}{ Kind } & \multicolumn{2}{|l|}{ Technical efficiency (\%) on the fifth day } \\
\cline { 2 - 4 } & Aktofit 0.2\% (standard) & Fitokomplekson 1 & Complexone-2P \\
\hline aphids buzynova & $85,46 \pm 3,16$ & $89,32 \pm 2,83$ & $81,10 \pm 6,12$ \\
\hline American white butterfly & $76,92 \pm 6,1$ & & $75,42 \pm 5,79$ \\
\hline Ordinary spider mite & $83,61 \pm 4,47$ & $91,63 \pm 4,47$ & $81,9 \pm 4,22$ \\
\hline $\mathrm{NCl}_{5}$ & & $84,38 \pm 3,08$ & \\
\hline
\end{tabular}

Note that in order to avoid the entry of stability of arthropod-herbivores to insecticides should be alternate use of biological drug Aktofit $0.2 \%$ and we developed products (Fitokomplekson 1 and complexone-2n). These techniques are economically viable and environmentally safe.

\section{Conclusions}

In plants of Sambucus L. in settlements marked steppe zone 9 species of arthropod herbivores, with 2 classes, 6 rows and 8 families. The most common are: buzynova aphids, thrips buzynovyy, spider mites and plain white American butterfly.

Most effective against American white butterfly was drug Fitokomplekson-1 technical efficiency which the 5 th day was $-91.7 \%$, higher biological Aktofit $0.2 \%$ (standard) is $14.7 \%$.

The most effective against aphids buzynovoyi also a drug Fitokomplekson-1 technical efficiency which the 5 th day was $-89.3 \%$, higher biological Aktofit $0.2 \%$ (reference) to $4.1 \%$.

To protect elderberry complex of pests recommended to alternate the use of drugs Aktofit $0.2 \%$ Fitokomplekson-1 and 2n-complexone. 


\section{References}

1. Gelyuta V.P. Flora of mushrooms of Ukraine. Mildew fungi / V.P. Heliuta. - K.: Science. Dumka, 1989. - $256 \mathrm{p}$.

2. Gusev V.I. The determinant of damages of trees and shrubs used in green construction / V.I. Gusev. - Moscow: Agropromizdat, 1989. - P. 31-36.

3. G. Dmitirev. Fundamentals of protecting green plantations from harmful arthropods / K .: "Harvest", 1969. - $411 \mathrm{p}$.

4. Dyadechko N.P. Trips, or fimbriothopterous insects of the European part of the USSR / N.P. Uncle.

- K .: Harvest, 1964. - 387 p.

5. Ermolenko V.M. Key insects / VM Эrmolenko, ZF Klyuchko. - K .: The Soviet school. - 1971. - 184 p.

6. Ivanovskaya O.I. Aphids of Western Siberia. Part 1. O.I. Ivanovskaya. - Novosibirsk: Science, 1977. $-272 \mathrm{p}$.

7. Keldysh M.A. Viruses and mycoplasmal diseases of woody plants / M.A. Keldysh, Yu.I. Pomazkov. Moscow: Nauka, 1985. - 233 p.

8. Klimenko S.V. Formation of collection and selection funds of non-traditional fruit plants in the National Botanical Garden of the NAS of Ukraine (1960-2005) / S.V. Klimenko // Introduction plants in the early twenty-first century: achievements and prospects of the research. Proceedings of the International Conference dedicated to the 70th anniversary of the National Botanical Garden them. MM Grisha NAS of Ukraine (19-21 September 2005). - Kyiv: Fitosotsiotsentr, 2005. - P. 38-41.

9. Kolesnik L. Collection of decorative forms Sambucus L. (Sambucaceae) National Botanic Garden of them. MM Grisha NAS Ukraine / L. Kolesnik, S. Klimenko // Bulletin of Kyiv National Univ Shevchenko. Introduction and conservation of plant diversity. - 2009, vol. 19-21. - S. 131-133.

10. Mamaev B.M. The determinant of insects in the European part of the USSR. Textbook. A manual for students of Biol. Specialties ped. In-tov / B.M. Mamaev, L.N. Medvedev, F.N. Pravdin. - Moscow: Enlightenment, 1976. - $304 \mathrm{p}$.

11. Lavitska Z.G. Lower plant. Experiments and observation / ZG Lavitska, V.A.Kovtun. - K .: The Soviet school, 1978. - $144 \mathrm{p}$.

12. Methodical recommendations on the definition of genera of four-legged pest-mites of agricultural crops and forest-park plantations. - Yalta: GNBS, 1981. - $28 \mathrm{p}$.

13. Methodological recommendations for the knowledge of mites-pests of fruit crops. - Yalta: GNBS, 1981. - $58 \mathrm{p}$.

14. Pat. 37503 Ukraine, A01G13 / 00. Environmentally safe means of protecting plants from pests complex "Fitokomplekson 1" / SN Vyhera, PY Chumak (Ukraine). Appl. 14.07.2008; Publish. 25.11.2008, Bull. Number 22.

15. Pat. 47717 Ukraine, A01R15 / 00. Environmentally safe means of protecting plants from pests complex "complexone-2n" / SN Vyhera, PY Chumak (Ukraine). Appl. 09.07.2009; Publish. 25.02.2010, Bull. Number 4.

16. Rupais A.A. The determinant of pests of ornamental and fruit trees and shrubs on damage / A.A. Rupais. - Riga: Zinatne, 1976. - 324 p.

17. Rupais A.A. Aphidodea of Latvia / A.A. Rupais. - Riga: ZINATNE, 1989. - 331 p.

18. Shevchenko S.V. Forest Phytopathology / S.V. Shevchenko, A.V. Cylinder. - K .: Vishcha shk. The main publishing house, 1986. - $384 \mathrm{p}$. 